\title{
ZARZĄDZANIE TŁUMEM W AKCJI RATOWNICZEJ
}

\author{
Kinga Karczewska \\ Wydział Psychologii, Akademia Ekonomiczno-Humanistyczna w Warszawie \\ ul Okopowa 59, 01-043 Warszawa, Polska \\ E-mail: kinkarczewska@gmail.com \\ ORCID: https://orcid.org/0000-0001-9994-2687
}

\begin{abstract}
Abstrakt
Cel badań: Celem pracy jest edukacja w zakresie efektywnego zarządzania tłumem w czasie akcji ratowniczej. Przekaz kierowany jest zarówno do profesjonalnych służb (ratownictwo medyczne, wodne, górskie, drogowe, Straż Pożarna itp.), jak i ratowników ochotników.

Metoda: Analiza literatury przedmiotu.

Wyniki i wnioski: Poznanie natury tłumu psychologicznego oraz mechanizmów, które nim rządzą daje osobom prowadzącym akcję ratowniczą narzędzia do skutecznego zarządzania. Wprowadzenie modułu zarządzania tłumem do szkoleń z zakresu szeroko pojętego ratownictwa jest pozytywnie odbierane przez szkolonych. $Z$ ich relacji wynika, że wiedza ta dodaje im pewności siebie i rzeczywiście potrafi znacząco zwiększyć efektywność akcji ratowniczej.

Słowa kluczowe: tłum psychologiczny, akcja ratownicza, zarządzanie tłumem, automatyczne wzorce zachowań, społeczny dowód słuszności, siła autorytetu, ratownictwo, psychologia społeczna, ratownictwo psychologiczne, psychologia w ratownictwie.
\end{abstract}

\section{Crowd control in rescue operations}

\section{Abstract}

Research purpose: The purpose of this paper is education towards effective crowd control during rescue operations. The message is directed to both professional services (medical, water, mountain rescue service, traffic police, fire brigades, etc.) and volunteer rescuers.

Method: Analysis of the subject's literature.

Results and conclusions: Understanding the nature of the psychological crowd and its mechanisms gives people conducting rescue operations the tools for effective control. The introduction of crowd control training in the field of rescue as it is broadly understood is positively received by the trainees. Their knowledge gives them confidence and can actually significantly increase the effectiveness of a rescue operation. 
Key words: psychological crowd, rescue operation, crowd control, automatic behavior patterns, social proof of authority, strength of authority, rescue, social psychology, psychological rescue, psychology in rescue.

\begin{abstract}
WPROWADZENIE
Żyjemy w epoce błyskawicznego rozwoju cywilizacyjnego. Niemal z dnia na dzień zaskakiwani jesteśmy nowymi rozwiązaniami technologicznymi. Mają one zastosowanie $\mathrm{w}$ wielu dziedzinach życia codziennego, jak np. bardziej zaawansowane urządzenia gospodarstwa domowego, szybsze środki transportu czy automatyzacja przemysłu. Rozwój technologiczny prowadzi jednocześnie do upowszechnienia dostępu do jego wytworów. W następstwie czego mamy możliwość robić pewne rzeczy szybciej, a obszary, które niegdyś były dla nas niedostępne, stają przed nami otworem. Jest jednak druga strona medalu. Kusząca szybkość, chęć ciągłego zwiększania efektywności, czy poruszanie się w rejonach, które wcześniej były dostępne wyłącznie dla wykwalifikowanych profesjonalistów, mogą prowadzić do brawury, a co za tym idzie do wypadków czy katastrof. Zatem postęp technologiczny zmusza nas również do rozwoju w dziedzinie przygotowania, planowania i prowadzenia akcji ratowniczych. Jak podaje Jerzy Szałek $(1979$, s. 7) akcja ratownicza to zbiór przedsięwzięć organizacyjnych, technicznych i taktycznych, ale także obszary związane z problematyką psychologiczną i społeczna, które mogą mieć istotny wpływ na jej przebieg i powodzenie. Działania ratownicze mogą mieć bardzo zróżnicowany charakter w zależności od środowiska, w jakim są prowadzone, rodzaju zdarzenia, jego strefy, złożoności, zaawansowania, liczebności poszkodowanych oraz dostępu do sił i środków. Jednakowoż możemy również wyróżnić ich stałe elementy takie jak czynniki wywołujące, obszar zagrożony, poszkodowani, ratownicy i - nierzadko - również obserwatorzy. W dalszej części tych rozważań to właśnie obserwatorom poświęcimy szczególną uwagę. W większym mieście możemy zaobserwować sytuacje , w których na ulicy, chodniku, przystanku, ławce czy parku leży człowiek, którego obojętnie mijają przechodnie. Czasem wokół niego zbiera się grupka bezczynnych obserwatorów. Skąd takie zjawisko? Wydawać by się mogło, że w tak dużym nagromadzeniu ludzi, powinien znaleźć się ktoś, kto pochyli się nad owym nieszczęśnikiem i spróbuje mu pomóc. Jeżeli nie możemy liczyć na wrodzony dar empatii przechodnia, to chociaż na wyedukowanie z zakresu obowiązku i znaczenia udzielania pierwszej pomocy. Edukacja ta formalnie obowiązuje nas już na poziomie szkoły średniej w ramach przedmiotu edukacja dla bezpieczeństwa (dawniej przysposobienie obronne), także $w$ ramach studiów wyższych, czy nawiązania stosunku pracy $\mathrm{w}$ formie umowy o pracę -szkolenie z zakresu pierwszej pomocy oraz bezpieczeństwa i higieny pracy. Równie powszechny dostęp do wiedzy z tego obszaru zapewniają nam szkolenia dla kierowców, motorniczych czy maszynistów. Można śmiało, choć czysto teoretycznie założyć, że wszyscy, którzy uczyli się w szkole średniej, skończyli studia wyższe, podpisali umowę o pracę lub też ukończyli kurs na prawo jazdy, powinni mieć świadomość, że za zaniechanie udzielenia pomocy osobie w stanie zagrożenia życia lub zdrowia, grozi do trzech lat pozbawienia wolności (Art. 162. § 1. kk). Idąc tym tropem można przyjąć, że skoro posiadają tę wiedzę, powinni, chociażby w obawie przed sankcją karną podjąć dzia-
\end{abstract}


łania ratownicze. Okazuje się jednak, że statystyka oraz założenia teoretyczne stają się bezradne w obliczu zawiłości ludzkiej psychiki, a konkretnie wobec automatycznych wzorów zachowań.

\section{SCHEMATY}

Każdego dnia od narodzin uczymy się funkcjonować w danym środowisku. Zgodnie z założeniami psychologii ewolucyjnej (Buss, 2001, s. 406) jesteśmy istotami społecznymi, gdyż życie w grupie umożliwia nam przetrwanie. Oznacza to, że przystosowanie się do reguł przyjętych przez dany kolektyw daje nam poczucie bezpieczeństwa, to zaś w piramidzie Maslowa stawiane jest jako najważniejsze, zaraz po potrzebach fizjologicznych (Zimbardo, Gerrig, 2012, s. 473). Uczymy się - a co za tym idzie - przystosowujemy na wiele sposobów; przez doświadczenia własne i innych, obserwacje, modelowanie (Zimbardo, Gerrig, 2012, s. 263). Nowo nabyta wiedza asocjuje do wcześniej powstałych struktur tworząc sieci semantyczne, których poszczególne fragmenty nazywamy schematami (Nęcka, Orzechowski, Szymura, 2006, s. 129). Są one jednym z wielu systemów oszczędności energetycznej, z których korzysta nasz organizm $\mathrm{w}$ nieustannym dążeniu do homeostazy, czyli stabilności, równowagi (Kalat, 2006, s. 294). To właśnie dzięki schematom nie musimy za każdym razem przed podjęciem decyzji czy działania, analizować dogłębnie całej sytuacji i jej każdego elementu. Pozwala to na szybsze działanie, w konsekwencji czego oszczędzamy własną energię (Aronson, Wilson, Akert, 1997, s. 128).

\section{REAGOWANIE KONTROLOWANE I HEURYSTYKI SĄDZENIA}

Psychologowie wyróżniają u ludzi dwa podstawowe style reakcji - reagowanie kontrolowane oraz heurystyki sądzenia (Cialdini, 2003, s. 21 za Chaiken, Trope, 1999; Khaneman, Slovic, Tversky, 1982). Reagowanie kontrolowane charakteryzuje się dokładną analizą sytuacji. Rozważamy każdy istniejący element, następnie dokonujemy wtórnej syntezy, oceny i dopiero podejmujemy decyzję o zachowaniu. Taki styl reagowania zwykle zachodzi gdy spełnione są odpowiednie warunki sytuacyjne, to znaczy: gdy sprawa dotyczy bezpośrednio nas; gdy pomyłka może nas dużo kosztować; gdy mamy potrzebę i możliwość dogłębnej analizy. Jest to zdecydowanie bardziej zachowawczy sposób reagowania, ale czy możemy powiedzieć, że bardziej adaptacyjny? Jak to w psychologii, odpowiedź jest złożona. Załóżmy, że rozważamy wzięcie kredytu hipotecznego, który będziemy spłacać przez najbliższe czterdzieści lat - wszystkie wyżej wymienione warunki są spełnione, a reagowanie kontrolowane zdaje się być najlepszym rozwiązaniem. Zastanówmy się jednak nad inną sytuacją. Wyobraźmy sobie, że idziemy sami lasem, nagle zza krzaków wychodzi na nas locha z warchlakami. Są spełnione dwa warunki - sytuacja dotyczy bezpośrednio nas i pomyłka może nas dużo kosztować. Czy uruchomimy zatem reagowanie kontrolowane? Raczej nie, ponieważ niespełniony jest trzeci warunek - możliwości dogłębnej analizy. Musimy działać szybko, w innym przypadku nasze życie lub zdrowie może być zagrożone. $\mathrm{O}$ ile nie popadniemy w stupor, prawdopodobnie podejmiemy błyskawiczna, instynktowną decyzję o ucieczce, a pomogą nam w tym heurystyki sądzenia. Heury- 
styki sądzenia jest to, jak trafnie określił Cialdini (2003, s. 21), "chodzenie na skróty" naszego umysłu. Nagromadzone w toku doświadczeń spostrzeżenia, informacje, osądy, poglądy, przekonania, stereotypy itp. tworzą sieć schematów, które pozwalają nam szybko reagować w sytuacjach znanych lub im podobnych. Ten styl reagowania również jest adaptacyjny, ponieważ dzięki usprawnianiu działania oszczędza energię, dodatkowo najczęściej okazując się trafionym i skutecznym. Nasz umysł lubi drogi na skróty, dlatego często je stosujemy. Mogą one jednak prowadzić do kosztownych pomyłek, jeśli okaże się, że użyliśmy ich zbyt pochopnie. Tutaj również możemy posłużyć się przykładami z życia. Kiedy przyjeżdżamy do obcego miasta i mamy zamiar nocować $\mathrm{w}$ hotelu, to $\mathrm{z}$ wcześniejszych doświadczeń prawdopodobnie będziemy wiedzieć, że najpierw trzeba znaleźć budynek z napisem HOTEL, następnie wejść do środka i znaleźć recepcję, tam zapytać o pokój. Jeśli mamy szczęście i wszystkie pokoje nie są aktualnie zajęte, $\mathrm{w}$ recepcji dokonamy meldunku, a po podpisaniu zobowiązania otrzymamy klucz do upragnionego pokoju. Schemat zwykle jest taki sam niezależnie od marki hotelu, miejscowości czy nawet kraju w jakim się znajdujemy, zatem istnieje duże prawdopodobieństwo, że za każdym razem nasza wypracowana heurystyka zadziała. Rozważmy teraz inny kazus. Idziemy ulicą w centrum dużego miasta, jest sobotni, letni wieczór. Na trawniku dostrzegamy leżącego mężczyznę w średnim wieku. Ubranie przybrudzone, twarz zaczerwieniona i lekko podrapana, można wyczuć od niego zapach alkoholu. Włączamy reagowanie automatyczne i w naszej głowie pojawia się błyskawiczna diagnoza: bezdomny alkoholik, leży bo lubi, bo taki ma styl życia. Decyzja: nie będę mu przeszkadzać, jak wytrzeźwieje, to sobie pójdzie. Oczywiście w dużej liczbie przypadków, może się okazać, że rzeczywiście jest to człowiek w kryzysie bezdomności z chorobą alkoholową ostatecznie takie często mamy doświadczenia. Osobną kwestią pozostaje ocena czy takiej osobie nie należy się z naszej strony pomoc. Niemniej jednak może się okazać, że nie mieliśmy racji. Możemy również przecież założyć, że jest to poważany profesor nauk humanistycznych, wolny od uzależnień, który po wypiciu kieliszka szampana na urodzinach córki, zasłabł na ulicy z powodu zawału mięśnia sercowego czy hiperglikemii. Prawdopodobnie mając tę wiedzę, chętniej podjęlibyśmy wobec niego czynności ratownicze, co wynika z jeszcze innych pułapek myślenia. W tym przypadku nasz błąd mógłby nieść za sobą tak ogromne koszty, jak czyjeś utracone życie. Takie pomyłki mają miejsce najczęściej w sytuacjach źle określonych (Maruszewski, 2011, s. 369), czyli takich, $\mathrm{w}$ których istnieje pełna niejasność dotycząca rozwiązania problemu, ale też tego czy sposób, w jaki ją spostrzegamy, jest zgodny z rzeczywistością. Obiektywny obraz danego zjawiska zaburzają tendencyjne sądy takie jak: heurystyka reprezentacyjności, dostępności, zakotwiczenia czy dopasowania (Nęcka, Orzechowski, Szymura, 2006, s. 550), które są odpowiedzialne za powstawanie zniekształceń poznawczych.

\section{WYBRANE RODZAJE HEURYSTYK}

Zjawiska indukowane przez zniekształcenia poznawcze, które są istotne $\mathrm{w}$ akcji ratowniczej, lub wręcz decydujące o jej podjęciu to: siła autorytetu, społeczny dowód słuszności, poczucie anonimowości, rozproszenie odpowiedzialności oraz efekt aureoli. Zacznijmy od fenomenu siły autorytetu. W świetle przeprowadzonych badań 
naukowych, jawimy się wręcz jako istoty niemal bezwolne wobec autorytetów. Dowiódł tego - nie pozostawiający złudzeń - eksperyment Stanleya Milgrama (1974), podczas którego osoby dorosłe ulegle wykonywały polecenia wykładowcy wyższej uczelni, wiedząc, że ich działania mogą doprowadzić do uszczerbku na zdrowiu, czy też utraty życia drugiej osoby. Zatrważające wyniki uzyskali również Holfing, Brotzman, Dalrymple, Graves i Pierce (1966), z których wynikało, że aż 95\% spośród badanych pielęgniarek podałoby - również w pełni świadomie - lek w dawce zagrażającej życiu lub zdrowiu pacjentowi, tylko dlatego, że takie dostały zlecenie (telefoniczne) od nieznanego im wcześniej lekarza. Cialdini (2003, s. 22) przytacza również kazus nazywany przez pracowników linii lotniczych „kapitanozą”, w którym wyznaczony na zastępstwo drugi pilot, uwiedziony sławą słynnego generała (pierwszy pilot), doprowadził do wypadku lotniczego, w skutek którego jego idol został kaleką. Błąd drugiego pilota polegał na bezwzględnym podporządkowaniu się domniemanemu rozkazowi generała, choć wiedział, że jego wykonanie najprawdopodobniej doprowadzi do katastrofy. Opisane przypadki wprawdzie są dość ekstremalne, jednak na co dzień również ulegamy temu zjawisku. Chociażby w przypadku przechodzenia na pasach dla pieszych na czerwonym świetle aż trzy i pół razy chętniej, gdy zainicjuje to osoba w eleganckim garniturze, niż osoba ubrana w stylu sportowym (Lefkowitz, Blake, Mouton, 1955). Kolejnym ze wspomnianych wcześniej zjawisk jest społeczny dowód słuszności. Najbardziej jaskrawym jego przykładem jest przypadek Kitty Genovese, ofiary ataku nożownika, który trwał 35 minut i rozgrywał się na oczach 38 sąsiadów, spośród których nikt nie pomógł dziewczynie. Tylko jeden ze świadków tego zdarzenia wezwał policję, jednak po wcześniejszej konsultacji telefonicznej ze znajomym z innej dzielnicy. Niestety w tym czasie Kitty była już martwa (Cialdini, 2003, s. 122). Na czym polega ten mechanizm? Postanowili zbadać to John Darley i Bob Latane (1968) organizując serię eksperymentów, których wyniki wskazuja, że wbrew pierwotnym założeniom, prawdopodobieństwo udzielenia pomocy osobie poszkodowanej jest odwrotnie proporcjonalne do liczby świadków zdarzenia. Przyczyną tego, wydawałoby się nielogicznego zjawiska, jest rozproszenie odpowiedzialności, czasem również wzmocnione poczuciem anonimowości (Eysenck H., M. 2000, s. 17). Wyobraźmy sobie sytuację: jesteśmy w pracy po godzinach, wraz z kolegą kończymy projekt, atmosfera jest napięta, gdyż termin wysłania oferty zbliża się nieubłaganie. Niespodziewanie kolega osuwa się z krzesła na podłogę tracąc przytomność. Zgodnie z wynikami badań, powinniśmy bezzwłocznie rozpocząć czynności ratownicze, w końcu jego los zależy wyłącznie od nas, co więcej to nasz kolega i wszyscy wiedza, kto $\mathrm{z}$ nim był w tym czasie w biurze. Teraz inna sytuacja: jedziemy zatłoczonym miejskim autobusem, trzy rzędy przed nami siedzi blady i spocony mężczyzna, nagle zamykają mu się oczy i opada głowa. Prawdopodobnie zaczniemy rozglądać się wokól ,jak inni reagują na zaistniałą sytuację, szczególnie ci, którzy siedzą w sąsiedztwie nieszczęśnika. Jeżeli nie reaguja, to stwierdzamy, że najwyraźniej nie ma takiej potrzeby, bo pewnie tylko przysnął, zresztą ci, którzy siedzą bliżej powinni udzielać pomocy. Na przykładzie drugiej sytuacji mamy możliwość obserwacji posługiwania się społecznym dowodem słuszności - inni nie reaguja, rozproszeniem odpowiedzialności - inni są bliżej oraz anonimowości - nikt mnie nie widzi i nie zna. Badania wykazały również, że osoby atrakcyjne mają większą szansę na uzyskanie pomocy, niż te mniej

Ogrody Nauk i Sztuk nR 2020 (10) 
pociągające (Benson, Karabenic, Lerner, 1976) - zależność tę nazywamy zjawiskiem aureoli (Cialdini, 2003, s. 157). Jest to mechanizm, w którym decydujemy o udzieleniu pomocy profesorowi, a odstępujemy od niej w przypadku bezdomnego, alkoholika.

\section{TŁUM PSYCHOLOGICZNY}

Wiemy już, co to są heurystyki sądzenia i automatyczne wzorce zachowań, skąd się one biorą i w jaki sposób działają. Dzięki temu łatwiej będzie zrozumieć, czym charakteryzuje się zjawisko tłumu psychologicznego i jakie mechanizmy nim rządzą. Tłum psychologiczny jest zbiorem przypadkowych osób, choć powiązanych ze sobą przez panujące czasowo okoliczności i tym przede wszystkim różni się od potocznie rozumianego tłumu. Żebyśmy mogli mówić o tłumie w sensie psychologicznym, muszą być spełnione pewne warunki, które wyróżnił i opisał Gustaw Le Bon (1994, s. 18). Po pierwsze jest to twór chwilowy, zatem nie możemy powiedzieć, że zespół z którym pracujemy od paru lat, jest tłumem psychologicznym. Mogą zdarzyć się jednak takie sytuacje, których specyfika może doprowadzić do przekształcenia grupy pracowników w ów twór. Znów będziemy potrzebowali do pomocy naszej wyobraźni. Załóżmy, że pracujemy w dużej korporacji, nagle przez głośniki w całym biurowcu zaczyna być nadawany komunikat: uwaga pożar, zalecana natychmiastowa ewakuacja z budynku. Nietrudno wyobrazić sobie wybuchającą panikę, wszyscy zaczynamy przepychać się do wyjścia, koncentrując się na uwolnieniu z terenu zagrożonego lub objętego pożarem. Przykładem zdarzenia, gdzie wystąpiło zjawisko owczego pędu, jest histeryczna ewakuacja z teatru Iroquis w Chicago z 1903 roku. W przeciagu dziesięciu minut, z powodu niegroźnego pożaru, niemal dwa i pół tysiąca widzów usiłowało jednocześnie opuścić salę, w efekcie czego około sześćset osób zostało ciężko rannych lub pozbawionych życia (Szałek, 1979, s. 123). Podczas ćwiczeń ewakuacyjnych zwykle wszystko idzie gładko i poprawnie, pozostajemy spokojni, wypełniamy swoje zadania i wydawane nam polecenia. To są właśnie kolejne cechy odróżniające tłum psychologiczny od przypadkowej grupy ludzi - wspólny kierunek myśli i uczuć,, a także zatarcie indywidualności na rzecz kształtowania zbiorowej duszy.To z kolei prowadzi do powstania właściwości innych niż poszczególnych osób wchodzących w jego skład. Upraszczając można powiedzieć, że każdy człowiek reprezentujący swój własny, indywidualny kolor, włączając się w tłum traci go na rzecz zalewającej wszystkich szarości. Le Bon (1994, s. 22) w swoim opracowaniu twierdzi wręcz, że "tłum to nagromadzenie miernoty, nigdy zaś inteligencji...". Możemy potraktować to jako potwierdzenie zatarcia indywidualności, ale też, co bardzo charakterystyczne, porzucenia działania opartego na logicznym myśleniu, na rzecz zachowań impulsywnych i emocjonalnych. Kontynuując tę myśl tłum psychologiczny będzie cechować: zmienność i drażliwość, przesada i prostota uczuć, a także nietolerancja, konserwatywność i autorytaryzm. $Z$ drugiej zaś strony typowa dla niego jest podatność na sugestię oraz łatwowierność (Le Bon, 1994, s. 28). Niestety tak silne scalenie się w grupie daje poczucie potęgi i zwalnia z poczucia odpowiedzialności. Możemy obserwować takie zjawiska, kiedy po meczach na ulice wylewa się czereda pseudokibiców, podczas manifestacji czy marszy tematycznych, a także podczas różnego rodzaju wypadków i katastrof. Z doświadczenia ratowników, zarówno zawodowych, jak i ochotni- 
ków wynika, że po chwili od zdarzenia formuje się tłum, który nierzadko określany jest przez nich "najgorszym przypadkiem medycznym”. Posiadając wiedzę na temat cech oraz mechanizmów charakteryzujących tłum psychologiczny, trudno się dziwić takiemu stwierdzeniu.

\section{ZARZĄDZANIE TEUMEM}

Sukces akcji ratowniczej zależy od wielu czynników, począwszy od tych kontrolowalnych, jak szybkość rozpoczęcia działań ratowniczych i zapobieganie eskalacji zdarzenia czy sprawne rozpoznanie i udzielenie adekwatnej pomocy technicznej, medycznej czy psychologicznej, skończywszy na niekontrolowalnych, jak warunki atmosferyczne lub charakterystyka i ukształtowanie terenu. Na niekontrolowalne - jak wskazuje ich nazwa - nie mamy wpływu, możemy jedynie łagodzić ich oddziaływania na prowadzone czynności. Skuteczność działań zależy od przygotowania merytorycznego ratowników. Właśnie dlatego jednym z wielu elementów szkoleń dla służb ratunkowych, takich jak Pogotowie Ratunkowe, Państwowa i Ochotnicza Straż Pożarna, poszczególne wydziały Policji i Straży Miejskiej, a także Wodnego, Górskiego, Tatrzańskiego Ochotniczego Pogotowia Ratunkowego, Ratownictwa Drogowego Polskiego Związku Motorowego oraz innych jednostek o charakterystyce ratowniczej, powinno być zarządzanie tłumem $w$ trakcie akcji ratunkowej. Na podstawie syntezy wiedzy naukowej z zakresu psychologii poznawczej i społecznej oraz doświadczeń empirycznych, można stworzyć proste narzędzia, które będą pomocne w zarządzaniu tłumem psychologicznym dla specyficznej sytuacji jaką jest akcja ratownicza. Narzędzia te można potraktować jednocześnie jako wskazania edukacyjne do szkoleń z zakresu ratownictwa dla służb profesjonalnych jak też ratowników ochotników. Po raz kolejny spróbujmy posłużyć się wyobraźnią by przenieść się w miejsce zdarzenia. Jesteśmy na ulicy, a wokół poszkodowanych uformował się już ścisły tłum gapiów. Zacznijmy od przejęcia dowodzenia - niezbędna do tego będzie siła autorytetu, jedna z heurystyk sądzenia opisana wcześniej. Atrybutami budującymi autorytet zawodowych ratowników są oczywiście mundur, oznakowane samochody, legitymacje czy odznaki służbowe. Ratownik cywilny może natomiast w tym celu posłużyć się powszechnie dostępną kamizelką odblaskowa, głośną i zdecydowaną artykulacją czy wręcz samą postawą swojego ciała. Kolejny krok, to rozbicie struktury tłumu psychologicznego, poprzez wyłowienie z niego pojedynczych jednostek. Znając jego właściwości, powinniśmy wiedzieć, że po zapytaniu czy ktoś może wezwać pomoc, istnieje nikłe prawdopodobieństwo zgłoszenia się entuzjastycznego ochotnika. Nawiązujemy zatem kontakt wzrokowy z wybraną osoba, wskazujemy ją ręka, pytamy jak ma na imię, dodatkowo podając jakiś charakterystyczny element jej ubioru. Przykład: Pani w czerwonej kurtce, jak Pani ma na imię? Wszystkie oczy kierują się na Panią w czerwonej kurtce, ona zaskoczona odpowiada: Kasia. W ten sposób przeszliśmy do kolejnego kroku po rozbiciu struktury, mianowicie do odebrania anonimowości. Kasiu wezwij pogotowie! To następne narzędzie - autorytarne wydawanie poleceń. Zauważmy, że nie ma tu prośby, zatem nie ma też miejsca na odmowę. W ten sposób wyłaniamy z tłumu osoby, rozdając im konkretne zadania. Zadania te powinny być niezbyt skomplikowane, tak aby można było sobie z nimi łatwo poradzić: wezwanie 
pomocy, przyniesienie apteczki czy automatycznego defibrylatora, powiadomienie ochrony obiektu i tym podobne. Szałek (1979, s. 125) w swoim opracowaniu przytacza słowa szwedzkiego lekarza, kierującego medycznym centrum obrony cywilnej Sztokholmu w czasie II wojny światowej - Walo von Greyerz, który twierdzi, że tłum można opanować, wydając mu właśnie zadania do wykonania. Warto zauważyć, że wartością dodaną jest rozdzielenie obowiązków, przesunięcie odpowiedzialności i odwrócenie uwagi od siebie, gdy tłum nie pozwala na wykonywanie niezbędnych czynności. Czasem wręcz można usłyszeć pomruki: „Kaśka, miałaś wezwać pogotowie, czemu tego jeszcze nie zrobiłaś?" Kiedy obserwujemy wśród tłumu narastanie negatywnych emocji i eskalację agresji, warto wyznaczyć osobę, która stanie za naszymi plecami, tak aby chroniła nas przed ewentualnym atakiem. Wykorzystujemy wtedy automatyczny wzorzec zachowania, jakim jest zaangażowanie i konsekwencja (Cialdini, 2003, s. 65). Pamiętajmy jednak, aby wybierać z tłumu osoby dorosłe, które $\mathrm{w}$ przypadku wzbierających złych nastrojów $\mathrm{w}$ tłumie, będą miały szansę sobie z nim poradzić. Ostatnią techniką która niestety może być kłopotliwa w kontekście ochrony danych osobowych, jest głośne poproszenie wybranej osoby o przygotowanie kartki i długopisu, w celu sporządzenia listy świadków zdarzenia. Technika ta ma na celu ostudzenie emocji, ale także spowodowanie oddalenia się niepożądanych gapiów.

Podsumowując, możemy stworzyć prosty schemat postępowania $\mathrm{z}$ tłumem w trakcie akcji ratowniczej, na potrzeby szkoleń zarówno ratowników profesjonalnych jak i ochotników. Schemat powinien zawierać wskazania dla działań ratownika krok po kroku w analogii do procedury prowadzenia resuscytacji krążeniowo-oddechowej. Dzięki wytycznym Europejskiej Rady Resuscytacji, ratownicy nie muszą znać tajników wiedzy kardiologicznej czy anestezjologicznej by w prawidłowy sposób przeprowadzić pośredni masaż serca i zastępczą wentylację. W przypadku zarządzania tłumem $w$ czasie akcji ratowniczej opracowanie prostego algorytmu postępowania pozwoli zdjąć zarówno z instruktora jak i potencjalnego ratownika obowiązek zgłębienia wiedzy z zakresu psychologii społecznej. Poniżej przedstawiam propozycję takiego schematu.

\section{SCHEMAT POSTĘPOWANIA $\mathrm{z}$ TLUMEM}

Przejmij dowodzenie - wykorzystując atrybuty ratownika oraz zdecydowaną artykulacje

Rozbij strukturę - wskazując konkretne osoby

Odbierz anonimowość - pytając wskazaną osobę o imię

Rozdziel zadania - wydając autorytarnie polecenia wybranym osobom

Sapolsky (2020, s. 213) opisuje, jak sytuacja stresowa zakłóca funkcjonowanie naszej pamięci, zwłaszcza upośledzając odtwarzanie informacji. Śmiało można założyć, że prowadzenie działań ratowniczych, czy to przez profesjonalistę, czy przez ochotnika, jest sytuacją stresową (Ogińska-Bulik, 2015, s. 19). Trudno zatem oczekiwać od ratownika, by w trakcie akcji ratowniczej sięgał pamięcią do teorii naukowych, aby wykonać niezbędne czynności. Byłoby to kłopotliwe nie tylko z powodu upośledzenia funkcji pamięci, ale również upływającego czasu. Powyższe wskazania są zwięzłe i proste, dzięki czemu łatwe do zapamiętania i odtworzenia. Jeżeli natomiast podczas 
szkolenia czas na to pozwala- warto rozwinąć każdy z punktów, podając przykłady obrazujące dane działanie. Pozwoli to na zbudowanie wokół zapamiętanego schematu sieci neuronalnej, która może ułatwić odtworzenie go z pamięci w sytuacjach stresowych (Sapolsky, 2020, s. 218). Jerzy Szałek (1979, s. 133) wykazuje, że sprawne działanie ratowników zależy nie tylko od ich przygotowania teoretycznego, ale także, a może przede wszystkim, od ćwiczeń $w$ warunkach zbliżonych lub identycznych do tych, w których przyjdzie im prowadzić akcję ratowniczą. Wskazane zatem jest, aby oprócz zapoznania się z teoretycznymi aspektami zarządzania tłumem psychologicznym, ćwiczyć i wypróbowywać przytoczone techniki. Wszak nikt nie osiąga mistrzostwa bez uprzednich przygotowań $i$ treningu.

\section{Bibliografia}

[1] Aronson, E., Wilson, T. D., Akert, R. M. (1997). Psychologia społeczna, serce i umyst. Poznań: Wydawnictwo Zysk i S-ka.

[2] Buss, D. M. (2001). Psychologia ezwolucyjna. Gdańsk: Gdańskie Wydawnictwo Psychologiczne.

[3] Caldini, R. B. (2003). Wywieranie wpływu na ludzi, teoria i praktyka. Gdańsk: Gdańskie Wydawnictwo Psychologiczne.

[4] Eysenck, H., M. (2000). Podpatrywanie umystu. Gdańsk: Gdańskie Wydawnictwo Psychologiczne.

[5] Kalat, J. W. (2006). Regulacja wewnętrzna. Biologiczne podstawy psychologii. Warszawa: Wydawnictwo Naukowe PWN.

[6] Le Bon, G. (1994). Psychologia ttumu. Warszawa: Wydawnictwo Naukowe PWN.

[7] Maruszewski, T. (2010). Myślenie i rozwiązywanie problemów. Psychologia poznania, umyst iświat. Gdańsk: Gdańskie Wydawnictwo Psychologiczne.

[8] Nęcka, E., Orzechowski, J. Szymura, B. (2006). Pojęcia i schematy. Psychologia poznawcza. Warszawa: Wydawnictwo Naukowe PWN

[9] Ogińska-Bulik, N. (2015). Dwa oblicza traumy, negatywne i pozytywne skutki zdarzeń traumatycznych u pracowników stużb ratowniczych. Warszawa: Difin SA.

[10] Sapolsky, R.,M. (2020). Dlaczego zebry nie mają wrzodów? Psychofizjologia stresu. Warszawa: Wydawnictwo Naukowe PWN.

[11] Szałek, J. (1979). Zarys psychologii akcji ratunkowych. Warszawa: Wydawnictwo Ministerstwa Obrony Narodowej.

[12] www.prawo.sejm.gov.pl. Ustawa z dnia 06.06.1997. Kodeks Karny.

[13] Zimbardo, P. G., Gerrig, R. J. (2012). Motywacja. Uczenie się i analiza zachowania. Psychologia $i$ życie. Warszawa: Wydawnictwo Naukowe PWN. 